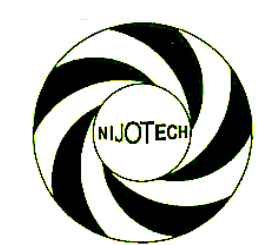

Nigerian Journal of Technology (NIJOTECH)

Vol. 39, No. 1, January 2020, pp. 140 - 147

Copyright@ Faculty of Engineering, University of Nigeria, Nsukka, Print ISSN: 0331-8443, Electronic ISSN: 2467-8821

www.nijotech.com

http://dx.doi.org/10.4314/njt.v39i1.15

\title{
SYNTHESIS OF FATTY ACID METHYL ESTERS FROM USED VEGETABLE OIL USING ACTIVATED ANTHILL AS CATALYST
}

\author{
E. O. Babatunde ${ }^{1, *}$, H. B. Saka ${ }^{2}$, M. A. Olutoye ${ }^{3}$, U.G. Akpan ${ }^{4}$ and M. Auta ${ }^{5}$ \\ $\mathbf{1 , 2}$, ChemicAl Engineering DePARTMENT, University of ILORIN, ILORIN, KWARA STATE, NIGERIA \\ 3, 4, 5, Chemical Engineering Dept., Federal University of TeChnology, MinNa, Niger State, NIGERIA \\ E-mail addresses; 1'babatunde.eo@unilorin.edu.ng, 2sakahavis@gmail.com, \\ 3m.olutoye@futminna.edu.ng, ${ }^{4}$ ugaekon@yahoo.co.uk, 5 manaseauta@futminna.edu.ng
}

\begin{abstract}
In this present study transesterification of used vegetable oil (UVO) using synthesized activated anthill as catalyst was investigated. The catalyst was prepared via calcination process, characterized by Brunauer-Emmett-Teller (BET), X-ray diffraction (XRD) and Fourier transform infrared (FTIR) techniques. From the BET analysis; calcination temperature has a positive impact on the textural properties. The XRD shows that the catalyst is crystalline in nature. Fatty acid methyl esters (FAME) was produced using thermally activated anthill as catalyst. The optimal FAME yield of $94.85 \%$ was obtained at Methanol/Oil (M/O) 9:1, catalyst loading 1.5 wt\%, reaction temperature of $65{ }^{\circ} \mathrm{C}$ and reaction time of $2 \mathrm{~h}$. The physico-chemical properties of UVO - FAME produced was found to be within the American Society for Testing and Methods (ASTM). Hence, the study reveals that used vegetable oil catalyzed by novel activated anthill could be an effective feedstock to produce sustainable energy.
\end{abstract}

Keywords: Anthills, FAME, Central composite design, Heterogeneous, used vegetable oil.

\section{INTRODUCTION}

There are many factors which makes renewable energy more attractive compared to fossil fuels. Fossil fuels have been found to cause damage to the environment by greenhouse gases emission. Concerns have emerged on renewability and sustainability of energy. Fortunately, there are so many attractive and alternative means of replacing the fossil fuel sources [1].

Among them, is the FAME also known as biodiesel, which has not been commercialized in developing countries like Nigeria due to the high cost of production. Biodiesel is a sustainable fuel that has many advantages such as low emissions, biodegradability and better lubricity $[2,3]$. Biodiesel is an alternative biodegradable and non-toxic fuel, which has very low sulphur and aromatics contents, although it has high emission of NOx. It is typically made by transesterification reaction of lipids (vegetable oil, waste oil, or animal fats) with a lowmolecular weight alcohol, such as methanol, ethanol, and propanol [4]. Various methods based on the types of catalyst have been used in the synthesis of biodiesel.

Industrially, the most common method for biodiesel production is basic homogeneous method which uses the solutions of $\mathrm{NaOH}$ or $\mathrm{KOH}$ as catalysts. The production of biodiesel by transesterification with base homogeneous catalysts has a drawback owing to the fact that the utilization of high free fatty acids (FFAs) feedstock in traditional biodiesel production processes leads to increased costs of purification. Also, the FFA in the feedstock is saponified by the homogeneous base catalyst, thereby producing excess soap [5] and decreasing the biodiesel yield. Saponification reactions during transesterification reaction, are categorically undesirable reactions because the catalyst is partially consumed as soap is being formed. Soaps emulsify the reaction products (biodiesel + glycerol) and the separation becomes difficult. Acidic homogeneous catalysts can also be used but, they are much slower than base catalysts

* Corresponding author, tel: +234 806-026-5818 
despite the increase in yield. Also, they require higher temperature and pressure during the reaction stage. However, the acid catalyst is usually employed for the reduction of acid value in most lower grade oil. This process is often termed esterification.

Esterification as a pretreatment step is normally carried out in a homogeneous phase in the presence of acid catalysts such as $\mathrm{H}_{2} \mathrm{SO}_{4}, \mathrm{HF}, \mathrm{H}_{3} \mathrm{PO}_{4}, \mathrm{HCl}$ and p-toluene and sulfonic acid [6, 7]. This pretreatment step has been successfully demonstrated using sulfuric acid [8]. Unfortunately, the use of the homogeneous sulfuric acid catalyst adds neutralization and separation steps to the synthetic process $[9,10]$. Also, this catalyst could be hazardous and corrosive in nature. The difficulty associated with the generation of catalyst wastes (homogenous catalysts are non-reusable) makes the use of homogeneous catalysts less favorable.

The problems listed above can be avoided when solid heterogeneous catalysts (base or acid) are applied. Heterogeneous catalysts have a lot of advantages. They are reusable, non-corrosive, and have potential to improve the quality of the biodiesel produced [11]. They have greater tolerance for water and FFAs. Examples of solid catalyst includes metallic oxides, carbon catalyst, clay, anthills e.t.c. The use of anthill is drawing attention, in that it comprises different metallic oxides and other active compounds which have the ability to catalyze the reaction towards production of biodiesel. In view of this, low grade oil such as Jatropha oil, castor oil, waste vegetable oil e.t.c could be transformed into biodiesel at lower cost.

UVO precisely, has nowadays been reckoned among the liquid wastes which are generated daily from various sources comprising households, restaurants, catering establishments, and industrial kitchens [12]. Due to the heat that is usually applied in frying processes, the physical and chemical features of the cooking oil change from their original form [13]. Waste vegetable oil which is expected to be treated and managed in a manner that could not be detrimental to the human health and the environment, is being disposed by consumers via sinks, waste bins, drainage systems, toilets, or directly to the immediate water bodies and lands. According to [14] greater quantity of UVO generated all over the world is being released into the environment. This act in the long run contributes to water and soil contamination, causes aquatic life distraction, sewer system blockages and overflow, increases water treatment and waste management cost, and consequently generates undesirable effects to the entire environmental system $[15,16]$.

However, waste vegetable oil contains high free fatty acid and moisture content, but this draw back could be overcome by the use of solid heterogeneous catalyst. Solid heterogeneous catalyst makes separation process step easier and reliable. The operating parameters could also cause drawback on the efficient use of waste vegetable oil for optimal biodiesel yield, hence, it is necessary to optimize this parameter toward optimal biodiesel yield. This work is aimed at developing and characterizing solid catalyst using activated anthill for biodiesel production over the influence of reaction time, reaction temperature, molar ratio of methanol to oil and catalyst loading. The random variation of the operating parameters was done by employing central composite design (CCD) which is a response surface methodology in design expert software.

\section{MATERIALS AND METHOD}

The anthill employed in this study is situated in the University of Ilorin, Nigeria on an elevation of 1170 feets above sea level, having latitude (N004036.409) and longitude (E003 $\left.{ }^{\circ} 18.627\right)$ with height and width of $3.55 \mathrm{~m}$ and $5.20 \mathrm{~m}$. The anthill was sprayed with insecticide before it was harvested. Waste vegetable oil was procured from a local food vendor in Ilorin, Kwara State. Analytical grade methanol used as reactant in the transesterification process was purchased from Central Research Lab Ilorin. The distilled water was obtained from Chemical Engineering Department Laboratory, University of Ilorin.

\subsection{Catalyst Preparation}

Anthill which was used as a catalyst was manually grinded using mortar and pestle. The crushed anthill was then wet beneficiated for $48 \mathrm{~h}$ under stirring for $24 \mathrm{~h}$ interval. It was left overnight to settle and later decanted to obtain fine anthill residue. The residue was dried at room temperature for $3 \mathrm{~h}$ and later dried in an oven at $110^{\circ} \mathrm{C}$ for $4 \mathrm{~h}$ to remove the excess water. The dried anthill was then sieved through a 75 $\mu \mathrm{m}$ mesh to obtain a fine powder. Thereafter, the powdered sample was thermally activated (calcination) in an electric furnace at a calcination temperature of $800^{\circ} \mathrm{C}$ for $2 \mathrm{~h}$. The resulting solid (activated anthill) was then ground, sieved and kept in a desiccator. 


\subsection{Catalyst Characterization}

The prepared activated catalyst was characterized to estimate its physical properties such as functional group, surface area, pore volume, and crystallinity. The physical properties of the catalysts were obtained by BET method using a Quantachrome Instrument (Nova station-A Model No: 11.03). The surface morphology of catalyst was studied using SEM images obtained from scanning electron microscope (JEOL JSM-6030, India). The basicity of the catalysts was determined by colorimetric titration method. The X-ray diffraction (XRD) patterns of the synthesized catalysts were recorded using a PAN England Philips diffractometer. The presence of functional groups on the sample surface was investigated by using a Shimadzu FTIR-8400. A technique of potassium bromide $(\mathrm{KBr})$ disk was used and the FTIR spectra were recorded in a range of $500-4000 \mathrm{~cm}^{-1}$.

\subsection{Transesterification of UVO using activated clay as Catalyst}

The catalyst was used in the transesterification process of waste vegetable oil. Transesterification of waste vegetable oil was carried out in a conical flask which was placed on top of a magnetic stirrer equipped with a thermostat. Central Composite Design was the optimization tool used to determine the optimum parameters that produced the highest yield of biodiesel. The major parameters considered for optimization of the transesterification process included methanol: oil ratio, reaction temperature, reaction time and catalyst loading and their values are tabulated in Table 1. The oil was heated up and the amount of methanol in different oil ratios was added to the oil in the flask. The synthesized catalyst was added at different loadings to the flask for a predetermined time. After the specified time, the reaction was stopped and then cooled in water bath and poured into the separating funnel. The mixture was left to stay for overnight undisturbed to allow separation of catalyst and glycerol from the biodiesel. Biodiesel obtained was separated and heated to 100 ${ }^{\circ} \mathrm{C}$ to vaporize excess methanol and water from the product. The weight of the biodiesel was measured and used to calculate the percentage yield using Equation 1.

Biodiesel yield $(\%)=\frac{\text { (mass of biodiesel obtained })}{(\text { mass of oil })} \times 100(1)$

\subsection{Design of experiment by Central Composite Design}

Design Expert 10.0.1 software was used for the regression and graphical analysis of the data. The highest value of biodiesel yield was taken as the response of the design experiment for transesterification process. The experimental data obtained by the above procedure was analyzed by the response surface regression using the following polynomial equation:

$Y=\beta_{0}+\sum_{j=1}^{n} \beta_{j} X_{j} \sum_{j=1}^{n} \beta_{j j} X_{j^{2}} \sum_{i-1}^{j-1} \sum_{j=2}^{n} \beta_{i j} X_{i} X_{j}+\varepsilon(2)$

Where $Y$ is the response, $i$ and $j$ are the linear and quadratic coefficients respectively, $X_{i}$ and $X_{j}$ are the uncoded independent variables, $\beta$ is the regression coefficient, $\mathrm{n}$ is the number of factors studied and optimized in the experiment. The Equation was also validated by carrying out confirmatory experiments.

\subsection{Fuel characterization}

Physico-chemical properties of the produced biodiesel were determined by following the standard methods suggested by ASTM (American Society for Testing and Materials). The important fuel properties such as kinematic viscosity, density and flash point were evaluated and compared with the properties of conventional diesel. Other fuel properties specifically defined for the biodiesel (acid value, free fatty acid, cloud point, and pour point) were also estimated following the standard methods.

\section{RESULTS AND DISCUSSION}

\subsection{Catalyst characterization}

The textural properties and basic sites of raw anthill and activated anthill catalyst are presented in Table 2. The result revealed that the surface area of activated anthill catalyst was higher than that of raw anthill. This implies that the calcination temperature has a positive effect on performance of activated anthill catalyst. According to [17] calcination temperature eliminates adsorbed gases, moisture content and volatile components, thereby creating pores on the surface of the catalyst.

Furthermore, the pore volume and average pore diameter of the activated anthill catalyst were determined to be $0.123 \mathrm{~cm}^{3} / \mathrm{g}$ and $23.22 \AA \mathrm{m}$ (Amstrong meter) respectively and found to be higher than those values obtained in the case of the raw anthill. This means that the activated anthill has a lot of active site and also has tendency to reduce 
mass transfer limitation. The increase in basic strength of the activated anthill reveals that Lewis base sites are active centers for transesterification. This result is in agreement with the work of [18]. Shown in Figure 1 is the FTIR spectrum of the activated anthill catalyst. The sharp wavenumbers of $1587.34 \mathrm{~cm}^{-1}, 1558.84 \mathrm{~cm}^{-1}$ and $441.16 \mathrm{~cm}^{-1}$ suggests the presences of vibrating stretch of carbonates and calcium oxides. The absorption bands at $1482.85 \mathrm{~cm}^{-}$ $1,1448.02 \mathrm{~cm}^{-1}$ and $1381.53 \mathrm{~cm}^{-1}$ indicate the presence of $\mathrm{Si}-\mathrm{H}$ deforming vibration. The XRD patterns characterizing the structural properties of activated anthill is also presented in Figure 2. The major peaks are observed at $2 \theta=32.2^{\circ}, 36.4^{\circ}, 47.2^{\circ}$, and $67.9^{\circ}$ while the peaks at $2 \theta=34.1^{\circ}$ was a characteristics of $\mathrm{Ca}(\mathrm{OH})_{2}$. Also, peaks at $2 \theta=31.2^{\circ}$ was attributed to $\mathrm{SiO}_{2}$. The two peaks indicate crystal phase. Thus, the catalyst tends to form crystals which are made up of $\mathrm{CaO}, \mathrm{Ca}(\mathrm{OH})_{2}$, and $\mathrm{SiO}_{2}$. The XRD result is in good agreement with FTIR result which also confirmed both $\mathrm{CaO}$ and $\mathrm{SiO}_{2}$.

Table 1: The Selected Process Parameters and Their Values at Different Levels

\begin{tabular}{rllll}
\hline Variables & Parameters & -1 & Level 0 & +1 \\
\hline$X_{1}$ & Methanol to oil molar ratio & $6: 1$ & $7.5: 1$ & $9: 1$ \\
$X_{2}$ & Temperature $\left({ }^{\circ} \mathrm{C}\right)$ & 50 & 60 & 70 \\
$X_{3}$ & Reaction Time (h) & 1 & 2 & 3 \\
$X_{4}$ & Catalyst loading (wt \%) & 0.5 & 1.25 & 2 \\
\hline
\end{tabular}

Table 2: Summary of the textural properties and basicity of anthill and activated clay catalyst.

\begin{tabular}{llllll}
\hline Sample & $\begin{array}{l}\text { BET } \\
\text { area }\left(\mathrm{cm}^{2} / \mathrm{g}\right)\end{array}$ & $\begin{array}{l}\text { surface } \\
\left(\mathrm{cm}^{3} / \mathrm{g}\right)\end{array}$ & $\begin{array}{l}\text { Total pore volume } \\
\text { diameter }(\AA \mathrm{m})\end{array}$ & $\begin{array}{l}\text { pore } \\
\text { Basic } \\
(\mathrm{mmol} / \mathrm{gcat})\end{array}$ & sites \\
\hline Raw Anthill & 90.12 & 0.0327 & 10.50 & 3.52 \\
Activated Anthill & 259.92 & 0.123 & 23.22 & 12.80 \\
\hline
\end{tabular}

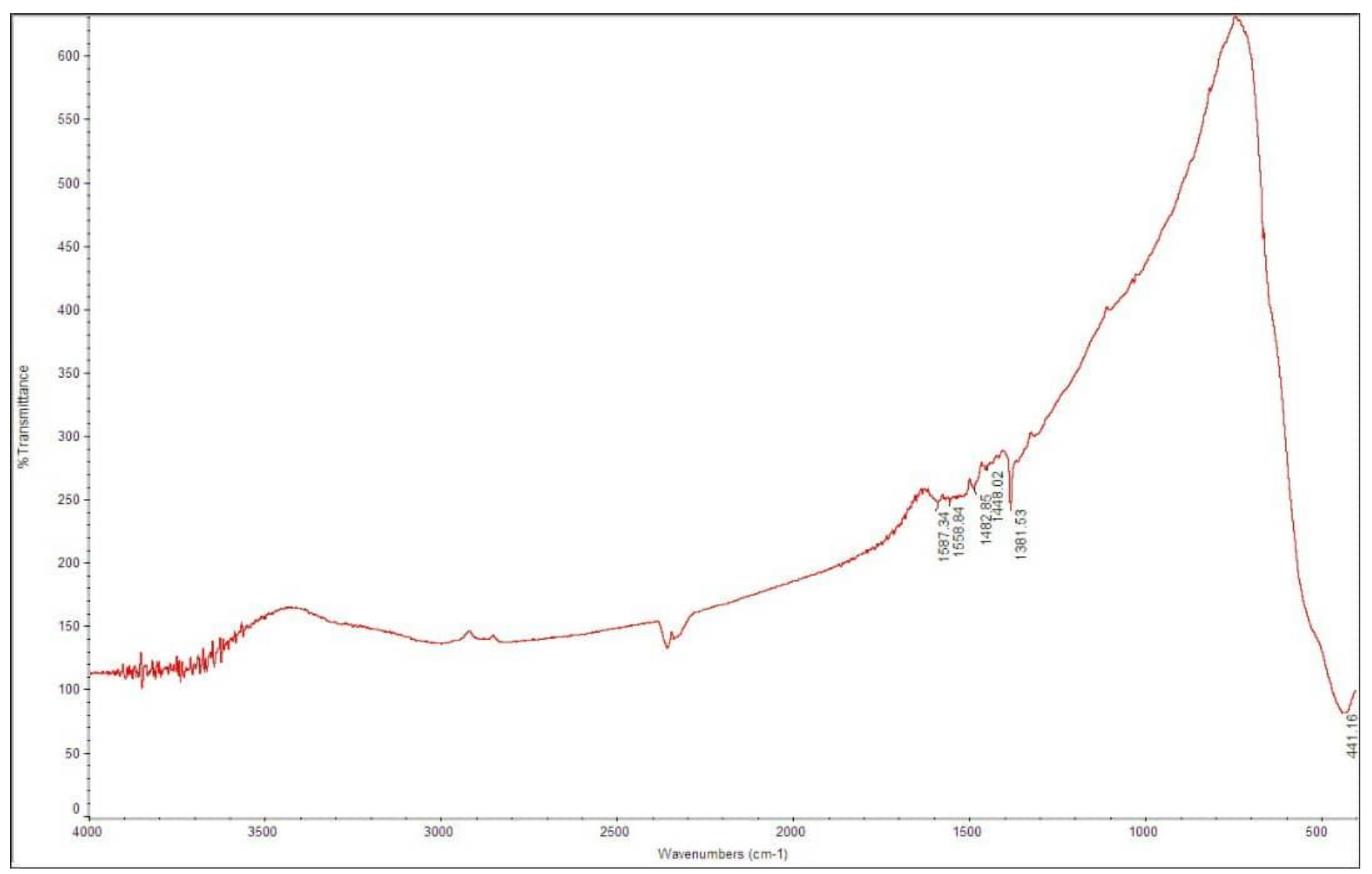

Fig. 1: FT-IR spectrum of Activated Anthill 


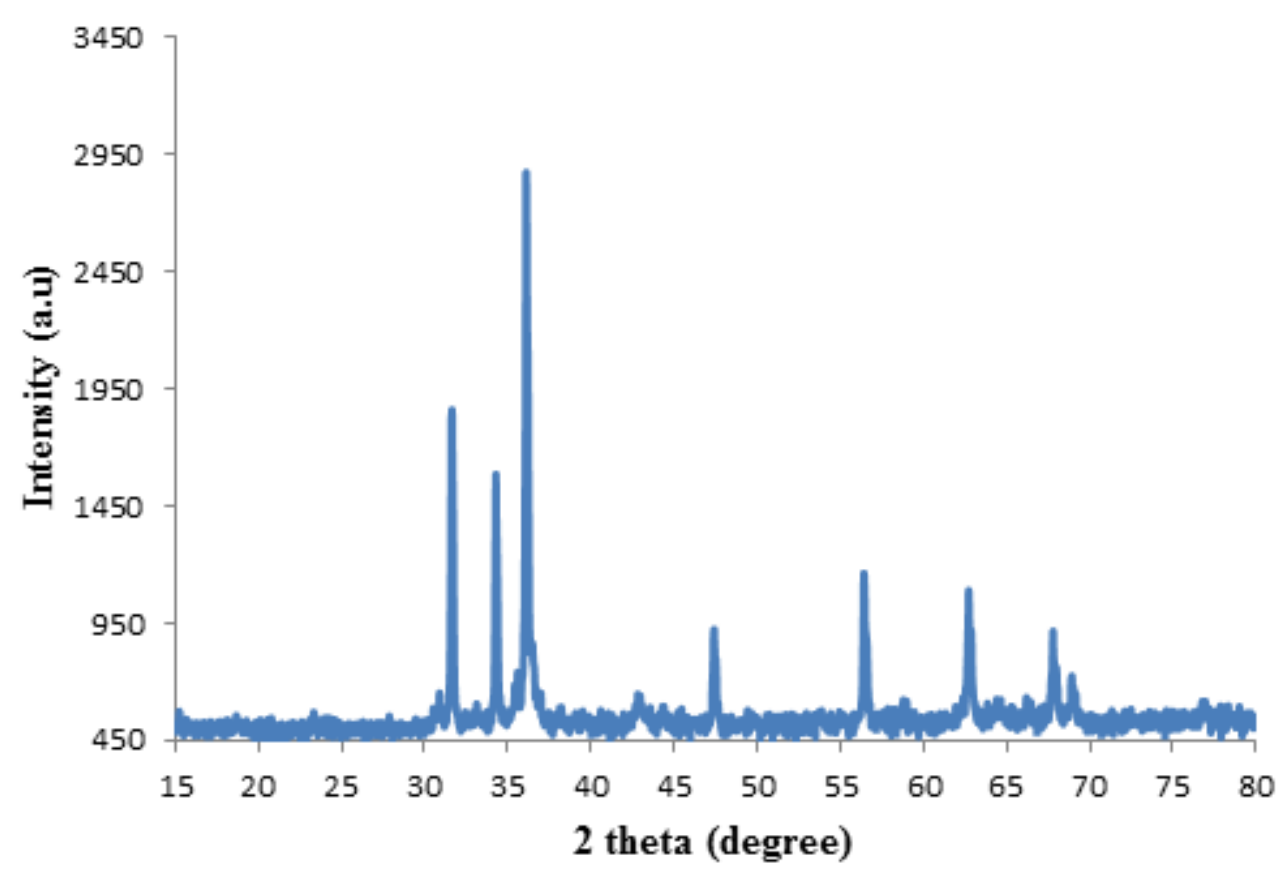

Fig. 2: XRD spectrum of Activated Anthill

\subsection{Analysis of the FAME produced}

\subsubsection{FTIR Analysis}

Figure 3 shows the FTIR spectrum of the FAME produced using activated anthill catalyst. The broad band at $3857 \mathrm{~cm}^{-1}$ was attributed to $\mathrm{O}-\mathrm{H}$ stretching vibration. The peaks at $2985.6 \mathrm{~cm}^{-1}$ and $2448.9 \mathrm{~cm}^{-1}$ were due to $\mathrm{C}-\mathrm{H}$ stretching vibration of methyl groups. The strong peaks at $1994.1 \mathrm{~cm}^{-1}(\mathrm{C}=\mathrm{O}$ ester) and $1871.2 \mathrm{~cm}^{-1}$ (C-O ester) were the carbonyl functional groups which confirms the presence of esters and are attributed to FAME while the peak at $872.2 \mathrm{~cm}^{-1}$ was attributed to $\mathrm{CH}_{3}$ groups. The presence of this functional groups confirmed the quality of the biodiesel produced and this result is in agreement with the work of $[19,20]$.

\subsubsection{Determination of the Physico-chemical Properties UVO}

UVO has high viscosity and free fatty acid and these properties have limited its direct use as fuel in diesel engines. The acid value of UVO used in this study was found to be $4.366 \mathrm{mg} \mathrm{KOH} / \mathrm{g}$, which corresponds to a free fatty acid value of $2.183 \%$. The Saponification value was calculated to be $125.3208 \mathrm{mg} \mathrm{KOH} / \mathrm{g}$ and molecular weight of the UVO was calculated using the acid value and Saponification value to be 1380.02 $\mathrm{g} / \mathrm{mol}$. The value of the molecular weight is different for different samples of oil due to some factors like the duration at which the oil was exposed to heat, oxygen and food during cooking [21]. Shown in Table 3 are the values of some other physico-chemical properties of the UVO used in this study.

\subsubsection{Physicochemical Properties of the FAME} Important fuel properties such as density, viscosity, pour point, cloud point, and flash point of the biodiesel produced were determined and the results were presented in Table 4. These results were compared to ASTM standard. Result obtained shows that the properties of biodiesel produced fell within the acceptable range, which is also in agreement with the work of $[22,23]$

\section{OPTIMIZATION OF PARAMETERS}

The optimization of individual responses was performed to achieve the highest yield of biodiesel based on the developed mathematical model, Equation (2). This equation is capable of optimizing the biodiesel synthesis process by performing the experiment at any set of condition. 


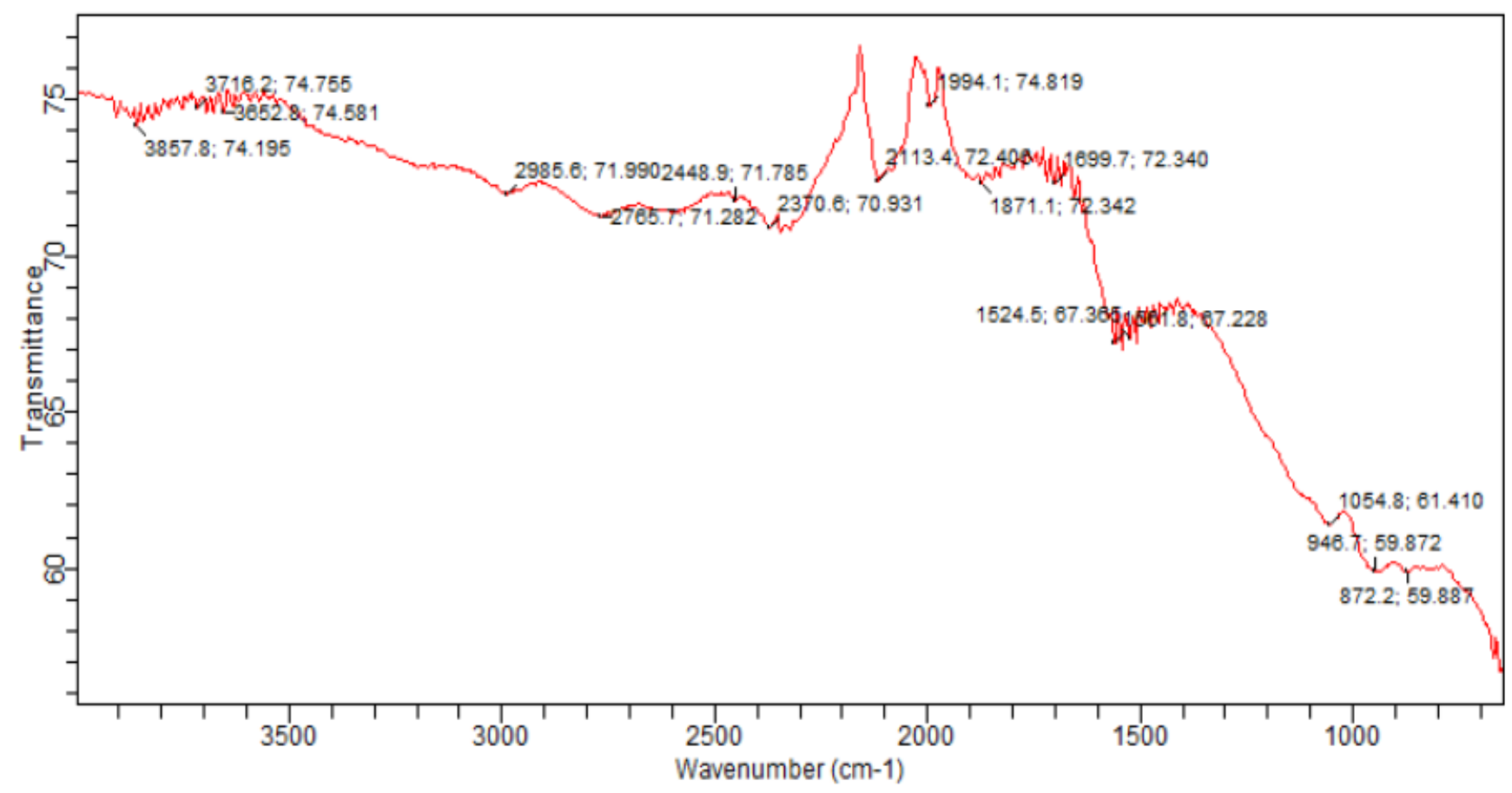

Fig. 3: FTIR spectrum of FAME

Table 3: Physicochemical Properties of UVO (Feedstock).

\begin{tabular}{ll}
\hline Properties & Values \\
\hline Acid value $(\mathrm{mg} \mathrm{KOH} / \mathrm{g})$ & 4.366 \\
Saponification value $(\mathrm{mg} \mathrm{KOH} / \mathrm{g})$ & 125.3208 \\
Free fatty acid $(\%)$ & 2.183 \\
Density $\left(\mathrm{g} / \mathrm{cm}^{3}\right)$ & 0.897 \\
Viscosity $(\mathrm{cP})$ & 11.0 \\
Molar mass $(\mathrm{g} / \mathrm{mol})$ & 1380.02 \\
\hline
\end{tabular}

Table 4: Biodiesel and fuel Properties

\begin{tabular}{lllll}
\hline $\mathrm{S} / \mathrm{N}$ & Parameters (units) & $\begin{array}{l}\text { Commercial } \\
\text { diesel }\end{array}$ & $\begin{array}{l}\text { UVO - Biodiesel / } \\
\text { FAME }\end{array}$ & $\begin{array}{l}\text { ASTM standard for } \\
\text { Biodiesel }\end{array}$ \\
\hline 1 & $\begin{array}{l}\text { Kinematic Viscosity } 40^{\circ} \mathrm{C} \\
\left(\mathrm{mm}^{2} / \mathrm{s}\right)\end{array}$ & - & 2.25 & 1.9 to 6.0 \\
2 & Density $\left(\mathrm{g} / \mathrm{cm}^{3}\right)$ & 0.844 & 0.869 & 0.860 to 0.900 \\
3 & Pour point $\left({ }^{\circ} \mathrm{C}\right)$ & -10 & -12 & -15 to -10 \\
4 & Flash point $\left({ }^{\circ} \mathrm{C}\right)$ & 70 & 138 & 100 to 170 \\
5 & Acid value $(\mathrm{mg} \mathrm{KOH} / \mathrm{g})$ & 0.34 & 0.354 & $<1.0$ \\
6 & Free fatty acid $(\%)$ & - & 0.177 & $<2.0$ \\
\hline
\end{tabular}

Table 5: Optimum process parameters for biodiesel yield

\begin{tabular}{llll}
\hline Parameters & Aim & Lower limit & Upper limit \\
\hline Methanol to oil molar ratio & Within range & $6: 1$ & $9: 1$ \\
Temperature $\left({ }^{\circ} \mathrm{C}\right)$ & Within range & 50 & 70 \\
Reaction Time $(\mathrm{h})$ & Within range & 1 & 3 \\
Catalyst loading $(\mathrm{wt} \%)$ & Within range & 0.5 & 2 \\
Biodiesel yield & Maximize & - & 94.8 \\
\hline
\end{tabular}


Table 6: Model validation under optimum condition

\begin{tabular}{llllllll}
\hline S/N & $\begin{array}{l}\text { Methanol: } \\
\text { oil molar } \\
\text { ratio }\end{array}$ & $\begin{array}{l}\text { Temperature } \\
\left({ }^{\circ} \mathrm{C}\right)\end{array}$ & $\begin{array}{l}\text { Reaction } \\
\text { Time }(\mathrm{h})\end{array}$ & $\begin{array}{l}\text { Catalyst } \\
\text { Loading }(\mathrm{wt} \\
\%)\end{array}$ & $\begin{array}{l}\text { Predicted } \\
\text { Biodiesel } / \\
\text { FAME yield }\end{array}$ & $\begin{array}{l}\text { Actual Biodiesel } \\
\text { yield }\end{array}$ & $\%$ Error \\
\hline 1 & $9: 1$ & 65 & 2 & 1.5 & 94.64 & 93.85 & 1.21 \\
2 & $9: 1$ & 65 & 2 & 1.5 & 94.64 & 94.85 & 0.21 \\
3 & $9: 1$ & 65 & 2 & 1.5 & 94.64 & 94.65 & 0.01 \\
\hline
\end{tabular}

The optimal value of input process parameters is shown in Table 5. Predicted response is found to be in good agreement with the actual response as shown in Table 6. Thus, signifying the accuracy of the model equation in prediction.

\section{CONCLUSION}

The activity of activated anthill catalyst in transesterification of UVO to FAME was successfully synthesized and investigated. The results of BET and basicity analyses revealed that surface area and high basic site increased with increase in calcination temperature respectively. The XRD spectrum shows that the catalyst was crystalline in nature. The optimized condition obtained at $94.85 \%$ yield of FAMEs are Methanol:oil 9:1, catalyst Loading 1.5 wt $\%$, reaction temperature $65{ }^{\circ} \mathrm{C}$ and reaction time 2 $\mathrm{h}$. The model was validated by comparing the actual response with the predicted. The compared values were in good agreement with each other. Hence, signifying the accuracy of the model.

\section{ACKNOWLEDGEMENT}

The authors would like to thank the Department of Chemical Engineering, University of Ilorin and Federal University of Technology Minna, Nigeria for their immense support during execution of the work.

\section{REFERENCES}

[1]. Silva Filho, S. C., Miranda, A. C., Silva, T. A. F., Calarge, F. A., de Souza, R. R., Santana, J. C. C., and Tambourgi, E. B. "Data on kinetic, energy and emission performance of biodiesel from waste frying oil", Data in brief, São Paulo, Brazil. Vol.18, 2018, pp 1224-1228.

[2]. Zhang, D., Duan, A., Zhao, Z., Wang, X., Jiang, G., Liu, J., and Jin, M. "Synthesis, characterization and catalytic performance of meso-microporous material Beta-SBA-15supported NiMo catalysts for hydrodesulfurization of dibenzothiophene", Catalysis Today, Beijing, China. Vol.175, Number 1, 2011, pp 477-484.
[3]. Suresh, M., Jawahar, C. P., and Richard, A. "A review on biodiesel production, combustion, performance, and emission characteristics of non-edible oils in variable compression ratio diesel engine using biodiesel and its blends", Renewable and Sustainable Energy Reviews, Coimbatore, India. Vol.92, 2018, pp 38-49

[4]. Amos, O., Ogunniyi, D. S., and Odetoye, T. E. "Production of biodiesel from Parinari polyandra B. seed oil using bio-based catalysts", Nigerian Journal of Technological Development, Ilorin, Nigeria. Vol.13, Number 1, 2016, pp 26-30.

[5]. Suffredini, D. F., Thyssen, V. V., de Almeida, P. M., Gomes, R. S., Borges, M. C., de Farias, A. M. D., and Brandão, T, "Renewable hydrogen from glycerol reforming over nickel aluminate-based catalysts", Catalysis Today, Salvador, Brazil. Vol.289, 2016, pp 96-104.

[6]. Verma, P., Sharma, M. P., and Dwivedi, G. "Prospects of bio-based alcohols for Karanja biodiesel production: An optimization study by Response Surface Methodology", Fuel, Roorkee, India Vol.183,2016, pp185-194.

[7]. Navajas, A., Campo, I., Moral, A., Echave, J., Sanz, O., Montes, M., and Gandía, L. M. "Outstanding performance of rehydrated Mg-Al hydrotalcites as heterogeneous methanolysis catalysts for the synthesis of biodiesel", Fuel, Pamplona, Spain.Vol. 211, 2018, pp 173-181.

[8]. Olutoye, M. A., and Hameed, B. H. "Production of biodiesel fuel by transesterification of different vegetable oils with methanol using $\mathrm{Al}_{2} \mathrm{O}_{3}$ modified $\mathrm{MgZnO}$ catalyst", Bio resource technology, Penang, Malaysia. Vol.132, 2013, pp 103-108.

[9]. Hojjat, M., Nayebzadeh, H., Khadangi-Mahrood, M., and Rahmani-Vahid, B. (2017). "Optimization of process conditions for biodiesel production over $\mathrm{CaO}-\mathrm{Al}_{2} \mathrm{O}_{3} / \mathrm{ZrO}_{2}$ catalyst using response surface methodology" Chemical Papers, Quchan, Iran. Vol.71, Number 3, pp 689-698.

[10]. Kutálek, P., Čapek, L., Smoláková, L., and Kubička, D. "Aspects of Mg-Al mixed oxide activity in transesterification of rapeseed oil in a fixed-bed reactor", Fuel Processing Technology, 
Pardubice, Czech Republic. Vol.122, 2014, pp 176-181.

[11]. Yusuff, A. S., Adeniyi, O. D., Olutoye, M. A., and Akpan, U. G. "Development and Characterization of a Composite Anthill Chicken Eggshell Catalyst for Biodiesel Production from Waste Frying Oil" International Journal of Technology, Minna, Nigeria.Vol.1, 2018, pp 111.

[12]. Ho, D. P., Ngo, H. H., and Guo, W. "A mini review on renewable sources for biofuel" Bioresource Technology, Brisbane, Australia. Vol.169, 2014, pp 742-749.

[13]. Odetoye, T. E., Onifade, K. R., AbuBakar, M. S., and Titiloye, J. O."Pyrolysis of Parinari polyandra Benth fruit shell for bio-oil production", Biofuel Research Journal, Ilorin, Nigeria. Vol 1,Number 3, 2014, pp 85-90.

[14]. Mazaheri, H., Ong, H. C., Masjuki, H. H., Amini, Z., Harrison, M. D., Wang, C. T., and Alwi, A. "Rice bran oil based biodiesel production using calcium oxide catalyst derived from Chicoreus brunneus shell", Energy, Kuala Lumpur, Malaysia. Vol. 144, 2018, pp 10-19

[15]. Corral, B. M., Lostado, L. R., Escribano G. R., Somovilla, G. F., and Vergara G. E. "An improvement in biodiesel production from waste cooking oil by applying thought multi-response surface methodology using desirability functions", Energies, La Rioja, Spain. Vol. 10, Number 1, 2017, pp130.

[16]. Yusuff, A. S., Adeniyi, O. D., Olutoye, M. A., and Akpan, U. G. "A review on application of heterogeneous catalyst in the production of biodiesel from vegetable oils". Journal of Applied Science and Process Engineering, Ado-Ekiti, Nigeria. Vol 4, Number 2, 2017a, pp 142-157.

[17]. Dhawane, S. H., Kumar, T., Halder, G. "Recent advancement and prospective of heterogeneous carbonaceous catalysts in chemical and enzymatic transformation of biodiesel", Energy
Conversion. Management, West Bengal, India. Vol 167, 2018, pp 176-202.

[18]. Amani H., Ahmad Z and Hameed B.H. "Highly active alumina-supported $\mathrm{Cs}-\mathrm{Zr}$ mixed oxide catalysts for low-temperature transesterification of waste cooking oil" Applied Catalysis A: General, Penang, Malaysia. Vol 48, 2014, pp1625.

[19]. Yusuff, A. S., Gbadamosi, A. O., Adeniyi, O. D., and Olutoye, M. A. "A Comparison of the Effects of Preparation Variables On Activity of Composite Anthill-Chicken Eggshell Catalyst for Biodiesel Production", Journal of Sustainability Science and Management, Ado-Ekiti, Nigeria. Vol 13, Number 1, 2018, pp133-146.

[20]. Yusuff, A. S. "Preparation and characterization of composite anthill-chicken eggshell adsorbent: Optimization study on heavy metals adsorption using response surface methodology" Journal of Environmental Science and Technology, AdoEkiti, Nigeria. Vol 10, Number 3, 2017b, pp 120130

[21]. Nisar, J., Razaq, R., Farooq, M., Iqbal, M., Khan, R. A., Sayed, M., and Rahman, I. "Enhanced biodieselproduction from Jatropha oil using calcined waste animal bones as catalyst", Renewable Energy, Peshawar, Pakistan. Vol 101, 2017, pp 111-119.

[22]. Ulusoy, Y., Arslan, R., Tekin, Y., Sürmen, A., Bolat, A., and Şahin, R. "Investigation of performance and emission characteristics of waste cooking oil as biodiesel in a diesel engine" Petroleum Science, Bursa, Turkey. Vol. 15, Number 2, 2018, pp 396-404.

[23]. Olutoye, M. A., and Hameed, B. H. "Kinetics and deactivation of a dual-site heterogeneous oxide catalyst during the transesterification of crude jatropha oil with methanol", Journal of Taibah University for Science, Minna, Nigeria. Vol 10, Number 5, pp 685-699. 